\title{
The Potentiality of Textile Sludge to be Used as Organic Manure
}

\author{
Tarek Hossain Raju ${ }^{1}$, Shakil Mahmud ${ }^{2}$, B. M. Sazzad Hossain ${ }^{3}$, Masrur Sabir Nafee ${ }^{4}$, Sayeda Ariana Ferdous ${ }^{5}$, \\ Md Mohsin Patwary ${ }^{6}$, Mohammad Nazmul Hossen ${ }^{7} \&$ Shahadat Hossain $^{8}$ \\ 1, 4, 8 Department of Environmental and Resource Management, Brandenburgische Technische Universität \\ Cottbus-Senftenberg, Germany \\ ${ }^{2}$ Department of Marketing and Merchandising, Sublime Greentex Ltd, Bangladesh \\ ${ }^{3}$ Department of Environmental Science, Jahangirnagar University, Bangladesh \\ ${ }^{5}$ Department of International Horticulture, Leibniz Universität Hannover, Germany \\ ${ }^{6}$ Department of Marketing and Merchandising, Renaissance Group, Bangladesh \\ ${ }^{7}$ Fabric Technologist, LC WAIKIKI, Bangladesh \\ Correspondence: Tarek Hossain Raju, Department of Environmental and Resource Management, \\ Brandenburgische Technische Universität Cottbus-Senftenberg, Germany. E-mail: rajubutex37@gmail.com
}

Received: August 9, 2020

Accepted: August 27, 2020

Online Published: August 28, 2020

doi:10.5539/mas.v14n9p63

URL: https://doi.org/10.5539/mas.v14n9p63

\begin{abstract}
Textile Industries of Bangladesh confront the environment a huge threat. It produces a huge amount of sludge from effluent treatment plants that is a burden for industries for its high volume and proper treatment cost thereby a huge threat to the environment. The present study aims to characterize the solid sludge of textile industry in terms of $\mathrm{pH}$, organic matter $(\mathrm{OM})$, nutrient elements $(\mathrm{N}, \mathrm{P}, \mathrm{K})$ and other metal elements through proper analytical methods. The average $\mathrm{pH}$ value of the sludge sample was 8.28 along with moisture content $60.64 \%$. The average content of the $\mathrm{OM}$ of the studied sludge samples was $11.73 \%$ and the average values of $\mathrm{N}, \mathrm{P}$ and $\mathrm{K}$ were $7.57 \%, 0.52 \%$ and $0.50 \%$, respectively. The studied metal $(\mathrm{Cr}, \mathrm{Zn} \mathrm{Mn}, \mathrm{Cd}, \mathrm{Pb}, \mathrm{As}$ and $\mathrm{Cu})$ content of the sludge revealed that the toxic heavy metals $\mathrm{Pb}, \mathrm{Cd}$ and As were not found in the samples. This study reveals that the amount of OM, N, P and $\mathrm{pH}$ is within the Waste concern compost standard (WCCS). The findings clearly show a potentiality of textile sludge as organic manure as they are rich in OM and plant nutrients and free from toxic heavy metals as well.
\end{abstract}

Keywords: metal element, nutrient element, organic matter, $\mathrm{pH}$, textile sludge

\section{Introduction}

The textile industry, the flagship of Bangladesh-now earns more than $70 \%$ of the country`s total export income. A recent report also revealed that Bangladesh's RMG (Ready Made Garments) exports to the world markets reached an all-time high value of over USD 9.35 billion in the end of 2007 (BGMEA, 2008). This textile and dyeing industries now viewed as a major environmental threat in the industrial area of Bangladesh and they contribute huge amounts of sludge in wastewater treatment processes (Karimet al., 2006). Although characteristics of sludge depend on the wastewater treatment process and sludge stabilization methods, it contains substantial amounts of toxic heavy metals (Chen et al., 2005; Singh et al., 2004). Another recent investigation reported that elevated levels of heavy metals in vegetables are found from the areas having long term uses of treated or untreated wastewater (Sharma et al., 2006, 2007).

Sludge Waste is classified either as hazardous or non-hazardous. Hazardous sludge waste is a waste that due to its (intrinsic) chemical or other properties poses a risk to the environment and/or human health (Wahlstromet al., 2016). Disposal of sludge from industrial Common Effluent Treatment Plant (CETP) is a serious issue because it can affect human and animals' health, and also environmental quality (Ahmadiet al., 2013). Exposure to physical and chemical compounds can produce a variety of adverse effects including non-communicable diseases, chromosomal changes, mutations, sperm abnormalities, early or late fetal loss, still births, decrease birth weights, altered sex ratio, birth defects and childhood malignancies (Soniet al., 2008). The resulting textile sludge has usually been disposed in landfill or incinerated with high associated costs. Modern waste management practices suggest recycling when possible (Rosa et al., 2007). Industrial activities lead to the generation of large amounts of sludge the disposal of which is a serious environmental issue because it contains harmful level of pollutants 
including heavy metals (Stylianouet al., 2007). Heavy metals disposal is a big concern due to their being nonbiodegradable and their tendency to bioaccumulation and they can affect human and animals' health and also environmental quality (Nair et al., 2008). Interest in such issues is constantly increasing because they have gradually been broadened with concepts such as sustainable development which implies ecological, economic and social responsibilities. Therefore, handling sludge is one of the most important challenges in wastewater management (Fytiliet al., 2008). There are several methods to handle sludge, each with advantages and limitations such as land use (Shiraniet al., 2010, Shomaret al., 2004), manufacturing construction materials (Vieira et al., 2006, Silva et al., 2007) wastewater treatment reagents (Huang et al., 2011) sludge dewatering (Ninget al., 2013) and landfills. This textile and dyeing industries now viewed as a major environmental threat in the industrial area of Bangladesh and they contribute huge amounts of sludge in wastewater treatment processes (Karimet al., 2006). Therefore, the present research is undertaken to know some physicochemical parameters of sludge containing water and usages of sludge in potential area.

\section{Materials and Method}

The sludge samples were randomly collected from different wastewater treatment units of different textile factories at Gazipur, Bangladesh. Sludge samples were weighed, cleaned and dried in an oven at $60^{\circ} \mathrm{C}$ and $120^{\circ} \mathrm{C}$ for 8 hours for organic and inorganic parameter determination, respectively. The dried sludge samples were gently ground and homogenized in an agate mortar and stored as stock sample. The $\mathrm{pH}$ and moisture content of raw sludge were measured by glass electrode $\mathrm{pH}$ meter as described by Jackson (1985). Total nitrogen and total phosphorus was determined by the method which described by Apha (2012). Organic matter was determined titrimetrically using Walkley and Black method with oxidation of organic matter with potassium dichromate described by Gosh et al.(1983). Exchangeable potassium was extracted by neutral ammonium acetate and determined directly by flame photometer (Black, 1965) at the wave length of 766.5 to $769.5 \mathrm{~nm}$. For the determination of sulfur, digested sample $(10 \mathrm{ml})$ was taken in the measuring flask followed by $10 \mathrm{ml}$ of acid seed solution and $5 \mathrm{ml}$ turbidimetric reagent using pipettes. Then shaking was performed frequently for 20 minutes and measured the absorbance on a spectrophotometer at $535 \mathrm{~nm}$. An aliquot of a well-mixed, homogeneous aqueous or solid sample is accurately weighed or measured for sample processing. For total recoverable analysis of a solid or an aqueous sample containing undissolved material, analytes are first solubilized by gentle refluxing with nitric and hydrochloric acids. After cooling, the sample is made up to volume, is mixed and centrifuged or allowed to settle overnight prior to analysis. For the determination of dissolved analytes in a filtered aqueous sample aliquot, or for the "direct analysis" total recoverable determination of analytes in drinking water where sample turbidity is $<1 \mathrm{NTU}$, the sample is made ready for analysis by the appropriate addition of nitric acid, and then diluted to a predetermined volume and mixed before analysis. For each determination, same experiment was also done for standard solutions and blank tests were also done by using blank digest. With these values, each calibration curve was constructed against known concentrations. Determination of trace elements in waters and wastes by inductively coupled plasma-mass spectrometry described by EPA (1994).Completely dried sludge sample was converted into fine powder by using ager mortar. $100 \mathrm{mg}$ bulk sample was taken with the help of microbalance\& packed in ultra clean polythene envelope. After that, sample packets are sealed with second packing. A blank \& three standard samples were prepared by the same process and taken into an irradiation tube. The Irradiation vial was then transferred to the Dry Centre Thimble (DCT) of TRIGA Mark-II Research Reactor. The samples were irradiated 40 minutes at $1 \mathrm{MW}$ by the neutrons at Neutron flux: $3.04 \times 1013 \mathrm{~N} / \mathrm{cm}^{2} \mathrm{~s}$. After that 40 minute irradiation time the samples were given 2 days cooling. Then the tube was unloaded and all the irradiated samples were kept in a lead castle for one day as a waiting time to decay the short lived nuclides. The acquisition of samples and measurements were performed by allowing various decay intervals in order to identify different nuclides:(1) decay time of 72 hours for the determination of Complete characterization of ETP sludge from textile industry Na; (2) after the decay time of 3 to 6 days, with a measuring time of $1.39 \mathrm{~h}$ to $2.23 \mathrm{~h}$ for the determination of $\mathrm{Pb}, \mathrm{Mn}, \mathrm{Cd}$, $\mathrm{Co}, \mathrm{Cr}, \mathrm{Ni}, \mathrm{Al}, \mathrm{Zn}, \mathrm{As}, \mathrm{Cu}, \mathrm{Fe}, \mathrm{La}, \mathrm{Ce}, \mathrm{Sm}, \mathrm{Sc}, \mathrm{Sb}, \mathrm{Na}$, and K. All tests were performed at SGS Bangladesh Limited, Dhaka, 1205, Bangladesh with pure reagents and materials.

\section{Results and Discussion}

\subsection{Physical Parameter}

Present study found that the physical characteristics (Table 1) of studied sludge were non granular, dark in colour, odorous and moist around $64.60 \%$. Bio sludge of secondary textile wastewater treatment processes content high organic carbon and plant nutrients, this bio-resource can be practically reused as raw feedstock for making organic fertilizers and building materials (Tsai, 2012) but also this sludge had high ammonia and $\mathrm{H}_{2} \mathrm{~S}$ contain cause odor problem. The moisture content will decrease if it dried or composted. 
Table 1. Physical Characteristics of studied textile sludge

\begin{tabular}{lll}
\hline Parameter & Condition & Standard condition (WCCS) \\
\hline Physical condition & Non granular form & Non granular form \\
Colour & Dark gray to black & Dark gray to black \\
Odor & Odor present & Absence of foul odor \\
Moisture content & $64.60 \%$ & Maximum $15 \%$ \\
\hline
\end{tabular}

3.2 Heavy Metals

\subsubsection{Chromium (Cr)}

The present research found that the average concentration of chromium in the sludge samples was $34.5 \mathrm{mgkg}-1$ with a ranged from 32-38 $\mathrm{mg} \mathrm{kg}-1$ (Table 2). The highest concentration of $\mathrm{Cr}$ was found in sample 3 and the lowest concentration of $\mathrm{Cr}$ was found $32 \mathrm{mg} \mathrm{kg}-1$ in sample 5 . This result indicates that analyzed sludge sample contained relatively lower amount of $\mathrm{Cr}$ than that of agricultural soil. Natural background level chromium in agricultural soil in Bangladesh is $100 \mathrm{mg} \mathrm{kg}-1$ (Table 3).

Table 2. The concentration of heavy metal in all sludge samples

\begin{tabular}{|c|c|c|c|c|c|c|c|}
\hline Metals & Sample 1 & Sample 2 & Sample 3 & Sample 4 & Sample 5 & Sample 6 & Mean \\
\hline $\mathrm{Cr}\left(\mathrm{mg} \mathrm{kg}^{-1}\right)$ & 34 & 36 & 38 & 34 & 32 & 33 & 34.50 \\
\hline $\mathrm{Cu}\left(\mathrm{mg} \mathrm{kg}^{-1}\right)$ & 78 & 156 & 140 & 150 & 90 & 99 & 118.83 \\
\hline $\mathrm{Zn}\left(\mathrm{mg} \mathrm{kg}^{-1}\right)$ & 73 & 306 & 270 & 80 & 250 & 230 & 201.50 \\
\hline $\operatorname{Mn}\left(\mathrm{mg} \mathrm{kg}^{-1}\right)$ & 833 & 1810 & 1719 & 1700 & 900 & 1500 & 1410.33 \\
\hline
\end{tabular}

Table 3. A comparison of heavy metal content $(\mathrm{mg} / \mathrm{kg})$ in soil from other regional study with present study

\begin{tabular}{cccccc}
\hline $\begin{array}{c}\text { Heavy } \\
\text { metal }\end{array}$ & $\begin{array}{c}\text { Present } \\
\text { study }\end{array}$ & $\begin{array}{c}\text { Permissible } \\
\text { limit } \\
\text { in india } \\
\text { Awashthi(2000) }\end{array}$ & $\begin{array}{c}\text { Ranges in } \\
\text { uncontaminated soil } \\
\text { in India } \\
\text { Bowen (1966) }\end{array}$ & $\begin{array}{c}\text { Ranges in } \\
\text { uncontaminated soil } \\
\text { in Bangladesh } \\
\text { DoE (2015) }\end{array}$ & $\begin{array}{c}\text { SEPA limit in } \\
\text { China }\end{array}$ \\
\hline $\mathrm{Cr}$ & 34.50 & NA & NA & 100 & 250 \\
$\mathrm{Zn}$ & 201.50 & $300-600$ & $300-600$ & 200 & 300 \\
$\mathrm{Cu}$ & 118.83 & $135-270$ & $100-200$ & 60 & 100 \\
$\mathrm{Mn}$ & 1410.33 & NA & $100-4000$ & NA & NA \\
\hline
\end{tabular}

3.2.2 Copper $(\mathrm{Cu})$

Average concentration of copper was $118.83 \mathrm{mg} \mathrm{kg}$ with ranged from 78-156 mg kg-1 (Table 2). The highest concentration of copper was found in sample 2, in addition the lowest concentration of copper was found $78 \mathrm{mg}$ $\mathrm{kg}-1$ in sample 1 . This result indicates that analyzed sludge sample contained relatively lower amount of copper than that of India (Table 3).

3.2.3 Zinc (Zn)

The present study found that the average concentration of zinc in the sludge samples was $201.5 \mathrm{mg} \mathrm{kg}^{-1}$ with a ranged from 73-306 mg kg-1 (Table 2). The Highest concentration of $\mathrm{Zn}$ was found in sample 2 and the lowest was found $73 \mathrm{mg} \mathrm{kg}^{-1}$ in sample1. This result indicates that average concentration of analyzed sludge sample contained relatively lower amount of $\mathrm{Zn}$ than that of ranges in uncontaminated soil of India (Table 3). The threshold natural background value of $\mathrm{Zn}$ in crop soils and paddy soils in China is $\leq 100 \mathrm{mg} / \mathrm{kg}$.

\subsubsection{Manganese (Mn)}

The present study found that the average concentration of manganese in the sludge samples was $1410.33 \mathrm{mg} / \mathrm{kg}$ although the concentration of $\mathrm{Mn}$ in the sludge sample ranged from $833-1810 \mathrm{mg} / \mathrm{kg}$ in Table 2 . The highest (1810 $\mathrm{mg} \mathrm{kg-1)}$ and lowest (833 mg kg-1) concentration of Mn was found in sample 2 and in sample1. This result 
indicates that average concentration of analyzed sludge sample contained within limit in uncontaminated soil of India (Table 3).

\subsection{Plant Macro Nutrient}

\subsubsection{Organic Matter}

The average content of organic matter (OM) of sludge was $11.725 \%$ observed from the study. The highest content of organic matter was found in sample 6 as well as the lowest content of organic matter was found in sample 5 . The OM in studied sludge sample was within the WCCS limit (Table4).The studied sludge contains high OM and the average OM value of sludge samples was $11.92 \%$. OM is the measure of carbon based material in the sludge. It can be considered as a pivotal component of soil because of its role in physical, chemical and biological processes. The organic contents of soil and organic manure are primary important in providing energy, substrates, and the biological diversity necessary to sustain numerous soil functions (Franzluebbers, 2002). According to Waste concern compost standard OM was optimum in studied sludge. The quality and quantity of organic matter is a central factor in determining fertilizer quality. The nitrogen content is relatively high compared to other element may be due to use of azo dye and biological treatment unit in production process.

Table 4. Plant macro nutrients and $\mathrm{pH}$ in studied textile sludge

\begin{tabular}{cccccc}
\hline Parameter & $\begin{array}{c}\text { Organic matter } \\
(\%)\end{array}$ & $\begin{array}{c}\text { Total nitrogen } \\
(\%)\end{array}$ & $\begin{array}{c}\text { Total phosphorus } \\
(\%)\end{array}$ & $\begin{array}{c}\text { Potassium } \\
(\%)\end{array}$ & $\mathrm{pH}$ \\
\hline Sample 1 & 11.25 & 8.5 & 0.56 & 0.06 & 8.4 \\
Sample 2 & 11.5 & 7.0 & 0.60 & 0.05 & 7.8 \\
Sample 3 & 13.0 & 8.3 & 0.57 & 0.06 & 8.5 \\
Sample 4 & 12.34 & 7.9 & 0.49 & 0.04 & 8.3 \\
Sample 5 & 10.17 & 6.99 & 0.44 & 0.02 & 8.8 \\
Sample 6 & 12.09 & 6.77 & 0.45 & 0.07 & 7.9 \\
Average & 11.73 & 7.57 & 0.52 & 0.05 & 8.28 \\
Standard (WCCS) & $10-25 \%$ & $0.5-4.0 \%$ & $0.5-1.5 \%$ & $1.0-3.0 \%$ & $6.0-8.5$ \\
\hline 3.3.2
\end{tabular}

3.3.2 Total Nitrogen

The average content of total nitrogen of sludge was $7.57 \%$. The highest content of total nitrogen $(8.5 \%)$ was found in sample 1 and the lowest content of total nitrogen $(6.77 \%)$ was found in sample 6 . The content of total nitrogen in studied sludge sample was within the WCCS limit (Table4). Nitrogen promotes rapid growth, increases leaf size and quality, hastens crop maturity and promotes fruits and seed development. Nitrogen is a constituent of amino acids, which are required to synthesize proteins and other related compound's, it plays a role in almost all plants metabolic processes. Crop response to fertilization with nitrogen (Urea) is generally very prompt, depending on stage of plant growth, rainfall and temperature (Ray, 1999). N was within suitable limit to make Organic fertilizer from sludge.

\subsubsection{Total Phosphorus}

Present study found that the average content of total phosphorus of sludge was $0.52 \%$. The highest content of total phosphorus $(0.60 \%)$ was found in sample 2 and the lowest was found in sample $5(0.45 \%)$. The content of total phosphorus in studied sludge sample was within the WCCS limit (Table4). Phosphorus (P) content of studied sludge is within range, can be allowed to use as raw material of organic fertilizer by considering the status of phosphorus. Long-term application of fertilizers containing phosphorus usually increases the water soluble and available $\mathrm{P}$ of soil and at the same time may result in $\mathrm{P}$ accumulation in soil (Mohammadiet al., 2009).

\subsubsection{Potassium}

The average content of potassium of sludge $0.05 \%$ was observed from the study. The highest content of potassium $(0.07 \%)$ was found in sample 6 as well as the lowest content of potassium $(0.02 \%)$ was found in sample 5.The content of potassium in studied sludge sample was within the WCCS limit (Table4). Potassium (K) is an essential macronutrient for plants. Potassium is associated with movement of water, nutrients and carbohydrates in plant tissue and Sulfur (S) is responsible for synthesis of amino acids required to synthesize proteins, also required for production of chlorophyll and utilization of phosphorus and other essential nutrients (Ray, 1999). The content of K 
and Sulfur (S) were very low compared to the standard. If $\mathrm{K}$ is deficient or not supplied in adequate amounts, growth is stunted and yields are reduced (Olson et al., 1987).

\section{$3.3 .5 \mathrm{pH}$}

The average $\mathrm{pH}$ value of studied sample was 8.28 which indicates the slights acidic condition. $\mathrm{pH}$ is the term used universally to express the intensity of acidic or alkaline condition of medium. It is the measure of hydrogen ion activity. The $\mathrm{pH}$ was within the range preferred by most soil bacteria (Brady, 2002). The optimum $\mathrm{pH}$ range for methanogenic bacteria is between 6 to 8 (Usamaet al. 2007).

\section{Conclusion}

$\mathrm{Cr}$ was found within the limits of Bangladesh govt. ranges in uncontaminated soil and $\mathrm{Zn}$ was almost within the limits. $\mathrm{Cu}$ was more than the permissible limits. In terms of organic matters and total Phosphorus, they were found within the limits of WCCS. Total Nitrogen was detected higher than the WCCS limit and Potassium was below limit. $\mathrm{pH}$ was found acceptable within limits. This properties are needed to be analyzed further with a little or even more mixture of nutrients for plants to produce organic manure. This is a theoretical hypothesis. This hypothesis is needed further practical work by producing sample manures form sludge of textile industry. Further study is needed to draw a generalized characteristics of sludge and a proper guideline to mix nutrients if needed.

\section{References}

Ahmadi M. (2013). Sludge characterization of a petrochemical wastewater treatment plant, Iran. Iranian J Health Sci., 1, 10-18. https://doi.org/10.18869/acadpub.jhs.1.2.10

Apha. (2012). Standard Methods for the Examination of Water and Wastewater, 22 nd ed., Method 4500-P J2011, Persulfate Method for Simultaneous Determination of Total Nitrogen and Total Phosphorus.

Awashthi, S. K. (2000). Prevention of Food Adulteration Act no 37 of 1954. Central and State Rules as Amended for 1999. 3rd Edn.,Ashoka Law House, New Delhi.

BGMEA (2008).Bangladesh Garments Manufactures and Exporters Association StatisticalReport, 2(2) April, 2008.http://www.just-style.com/factsheet.aspx?id=276.

Black, C.A. 1965. Methods of Soil Analyis. Part I and Part II. Amer. Soc. Agron. Inc. Pub. Madison. Wiscosin. USA. https://doi.org/10.12691/ijebb-3-1-3

Bowen, H. J. M., (1966). Trace Elements in Biochemistry. 1st Edn., Academic Press, New York, ISBN-13: 9780003686463.

Brady, N. C., Ray R. W. (2002). The Nature and Properties of Soils, 363-368. Thirteenth ed. Pearson education Pte.Ltd.

Chen, Y., Wang C., \& Z. Wang. (2005). Residues and source identification of persistent organic pollutants in farmland soils irrigated by effluents from biological treatment plants. Environ. Int., 31, 778-783. https://doi.org/10.1016/j.envint.2005.05.024

DoE. (2015). Bangladesh Standards and Guidelines for Sludge Management, Dhaka, Bangladesh.

EPA. U.S. (1994). "Method 200.8: Determination of Trace Elements in Waters and Wastes by Inductively Coupled Plasma-Mass Spectrometry," Revision 5.4. Cincinnati, OH.

Franzluebbers, A.J. (2002). Soil organic matter stratification ratio as an indicator of soil quality. Soil \& Tillage Research, 66, 95-106. https://doi.org/10.1016/j.still.2008.09.003

Fytili D, Zabaniotou A. (2008). Utilization of sewage sludge in EU application of old and new methods A review. Renew Sust Energ Rev., 12, 116-40. https://doi.org/10.1016/j.rser.2006.05.014

Gosh, A.B., Bajaj, J.C., Hasan, R. \& SIngh, D. (1983). Soil and Soil water testing method. A laboratory Manual, Division of Soil Science and Agricultural Chemistry, IARI, New Delhi-110012, 1-45. https://doi.org/10.9734/JAERI/2016/21565

Karim, M.M., A.K. Das \& S.H. Lee. (2006). Treatment of colored effluent of the textile industry in Bangladesh using zinc chloride treated indigenous activated carbons. Anal.Chimica.Acta., 576, 37-42. https://doi.org/10.1016/j.aca.2006.01.079

Mohammadi, M.K., \& Shariatmadri, H. (2009). Cumulative and residual effects of Organic fertilizer Application on selected soil Properties, Water Soluble P,Olsen-P and P sorption Index. J. Agr. Sci.Tech., 1, 487-497. 
Nair A, Juwarkar AA, Devotta S. (2008). Study of speciation of metals in an industrial sludge and evaluation of metal chelators for their removal. $J$ Hazard Mater, 152, 545-53. https://doi.org/10.1016/j.jhazmat.2007.07.054

Ning X-a, Luo H, Liang X, Lin M, Liang X. (2013). Effects of tannery sludge incineration slag pretreatment on sludge dewaterability. ChemEng J, 221, 1-7.

Olson, W.H., Uria, K., Carlson, R.M., Krueger, W.H., \& Pearson, J. (1987). Correcting potassium Deficiency in Prune Trees is Profitable. California agriculture, 41, 2.

Ray, M., Tucker. (1999). Essential Plant Nutrients: their presence in North Carolina Soils and role in plant nutrition, NCDA and NS.

Rosa EV, et al. (2007). Textile sludge application to non-productive soil: physico-chemical and phytotoxicity aspects. Ecotoxicol Environ Saf., 68, 91-97. https://doi.org/10.1016/j.ecoenv.2006.06.006

Sharma, R.K., M. Agrawal \& F. Marshall. (2007). Heavy metal contamination of soil and vegetables in suburban areas of Varansi, India.Ecotoxicol. Environ. Safety, 66, 258-266. https://doi.org/10.1016/j.ecoenv.2005.11.007

Sharma, R.K., M. Agrawal \& F.M. Marshall. (2006). Heavy metal contamination in vegetables grown in wastewater irrigated areas of varanasi, India. Bull. Environ. Contaminat.Toxicol., 77, 312-318. https://doi.org/10.1007/s00128-006-1065-0

Shirani H, HajAbbasi M, Afyouni M, Dashti H. (2010). Cumulative Effects of Sewage Sludge on Soil Physical and Chemical Characteristics. Water andWastewater, 3, 28-36.

Shomar BH, Müller G, Yahya A. (2004). Potential use of treated wastewater and sludge in the agricultural sector of the Gaza Strip. Clean Technol Environ Policy, 6, 128-137. https://doi.org/10.1007/s10098-003-0228-5

Silva M, Mater L, Souza-Sierra M, Corr^ea A, Sperb R, Radetski C. (2007). Small hazardous waste generators in developing countries: use of stabilization/solidification process as an economic tool for metal wastewater treatment and appropriate sludge disposal. $J$ Hazard Mater, 147, 986-90. https://doi.org/10.1016/j.jhazmat.2007.01.128

Singh, R.K. \& M. Agrawal. (2005). Atmospheric depositions around a heavily industrialized area in a seasonally dry tropical environment of India. Environ. Pollut., 138, 142-152. https://doi.org/10.1016/j.envpol.2005.02.009

Soni, H.I., et al. (2008). Assessment of teratogenecity and embryotoxicity of sludge from textile industries at Pali (India) in Swiss albino mice exposed during organogenetic period. J Environ Biol., 29, 965-974.

Stylianou MA, Kollia D, Haralambous K-J, Inglezakis VJ, Moustakas KG, Loizidou MD. (2007). Effect of acid treatment on the removal of heavy metals from sewage sludge. Desalination, 215, 73-81. https://doi.org/j.desal.0000.00.000

Tsai, W.T. (2012). An Analysis of Waste Management Policies on Utilizing Biosludge as Material Resources in Taiwan, Sustainability, 4(8), 1879-1887. https://doi.org/10.3390/su4081879

Usama, Z., Dae-Yeol, C., Binixin, W., \& Shulin, C. (2007). Producing Energy and Fertilizer from Organic $\begin{array}{lllll}\text { Municipal Solid Waste, Ecology publication } & \text { No.07-07-024, } & 10 .\end{array}$ https://doi.org/10.1371/journal.pone.0181621 J

Vieira C, Andrade P, Maciel G, Vernilli Jr. F, Monteiro S. (2006). Incorporation of fine steel sludge waste into red ceramic. Mater SciEng, A 427, 142-7. https://doi.org/10.1016/j.msea.2006.04.040

Wahlstrom M, et al. (2016). Amendments to the European Waste Classification regulation; Hazardous waste classification. Norden, 1-123. https://doi.org/10.6027/TN2016-519

\section{Copyrights}

Copyright for this article is retained by the author(s), with first publication rights granted to the journal.

This is an open-access article distributed under the terms and conditions of the Creative Commons Attribution license (http://creativecommons.org/licenses/by/3.0/). 